\title{
ACTIVE COIL-CORE SYSTEM AS A PART OF RIGID BODY SUPPORT AND ITS INFLUENCE ON THE BODY VIBRATIONS
}

\begin{abstract}
SUMMARY
In the paper we took into account the influence of the actively controlled coil dampers introduced into vibrating body supports. The body was considered as moving mass centre of 3-degrees-of-freedom. Investigated object was located on four supports. Body dynamics was described by means of Newton and Euler equations. Body vibrations were caused by statically unbalanced rotor located inside the object. In the control system the coils with the movable cores were used as the executive elements (controllable stiffness). In the closed-loop system the PD regulators were introduced into each support. The coils current was controlled by means of pulse width modulated (PWM) generators. In the article we presented the time characteristics and the frequency responses of the investigated system. Differences between open (non-controlled) and closed-loop (actively controlled) system were shown. Responses to the rotor perturbations were also calculated. Finally, the main advantages and disadvantages of the proposed solution were discussed. The further work directions were also indicated.
\end{abstract}

Keywords: oil with movable core, vibroisolation, inductance gradient, vibration control

\section{AKTYWNY UKEAD CEWKA-RDZEŃ JAKO CZEŚĆ PODPORY BRYEY SZTYWNEJ ORAZ JEGO WPEYW NA DRGANIA}

$W$ niniejszej pracy rozpatrzono wplyw aktywnie kontrolowanych cewkowych tlumików drgań umieszczonych w podporach drgajacej bryty. Badana bryła została opisana jako punkt materialny o trzech stopniach swobody. Badany obiekt umieszczono na czterech podporach. Dynamike ciała opisano równaniem Newtona i Eulera. Drgania bryty byly wywołane statycznie niewyważonym wirnikiem umieszczonym we wnętrzu bryty. W układzie sterowania, jako elementy wykonawcze wykorzystano cewki z ruchomymi rdzeniami. Do każdej z podpór wprowadzono zamknięta pętle sterowania z regulatorem proporcjonalno-różniczkujacym (PD). Prąd w cewkach byt regulowany za pomoca generatorów impulsowych o zmiennym wypetnieniu (PWM). W niniejszej pracy przedstawiono charakterystyki czasowe oraz odpowiedzi częstotliwościowe badanego układu. Pokazano różnice pomiędzy układem otwartym (bez sterowania) $i$ zamkniętym (sterowanym aktywnie). Wyznaczono również odpowiedzi układu na zaburzenia wywotywane przez wirnik. W pracy omówiono główne zalety $i$ wady proponowanych cewkowych thumików drgań. Wskazano również kierunki przyszlych badań.

Slowa kluczowe: cewka z ruchomym rdzeniem, wibroizolacja, gradient indukcyjności, sterowanie drganiami

\section{INTRODUCTION}

Vibroisolation problems have been considered for many years. The first scientific works were connected with passive methods. A vast survey of such methods was presented in numerous monographs (Goliński 1979, Osiński 1979). Such approaches appeared as in-sufficient and gradually the semi-active and active methods were introduced, for example in the reference (Kowal 1996). Actuators are the main problem of the active vibroisolation systems. Vibrations are fast processes and actuators should work in a wide range of frequencies. Up to now, there are a few kinds of actuators which fulfil such requirements: pneumatic (up to $10 \mathrm{~Hz}$ ) (Krzeniowski 2004), hydraulics (up to $100 \mathrm{~Hz}$ ) (Krzeniowski 2004), magnetic bearings (up to $1000 \mathrm{~Hz}$ ) (Gosiewski 2003), magnetorheological dampers (up to $1000 \mathrm{~Hz}$ ) (Martynowicz 2006, Sapiński 2004), and electromagnetic supports (up to $1000 \mathrm{~Hz}$ ) (Gosiewski 2003). The last three cases indicate the electric supply as the best solution for fast actuators in vibration control systems.
In this paper the active coils-core systems were proposed and investigated as an additional vibroisolation support.

\section{INVESTIGATED SYSTEM}

The investigation of the active damping of a rigid body vibration situated on four supports was presented in this paper. The body dimensions $\left(x_{b}, y_{b}, z_{b}\right)$ and support locations (I, II, II, IV) are shown in Figure 1. The body mass centre $C$ did not coincide with its geometric centre. The localization of the $C$ point was described by $x_{c b}, y_{c b}$ and $z_{c b}$ parameters. The perturbation force $\left(F_{z}\right)$ was caused by a statically unbalanced rotor with axis of rotation parallel to the $x$-axis. The $F_{z}$ force acted in the point $R$. Each body support was composed of a spring, a damper, and two coils with movable core placed between them (Fig. 2). The coils were connected with pulse width modulated (PWM) power supplies. The described magnetic system served as a controllable damper introduced into the support. The support displacement was used as a PD controller input signal. The

\footnotetext{
* Department of Automatic Control and Robotics, Faculty of Mechanical Engineering, Bialystok University of Technology, Bialystok,

Poland; m.kondratiuk@pb.edu.pl, gosiewski@pb.edu.pl, leszek.ambroziak@gmail.com
} 
described system was collocated because the measurement of the displacements took place in points where the control forces acted.

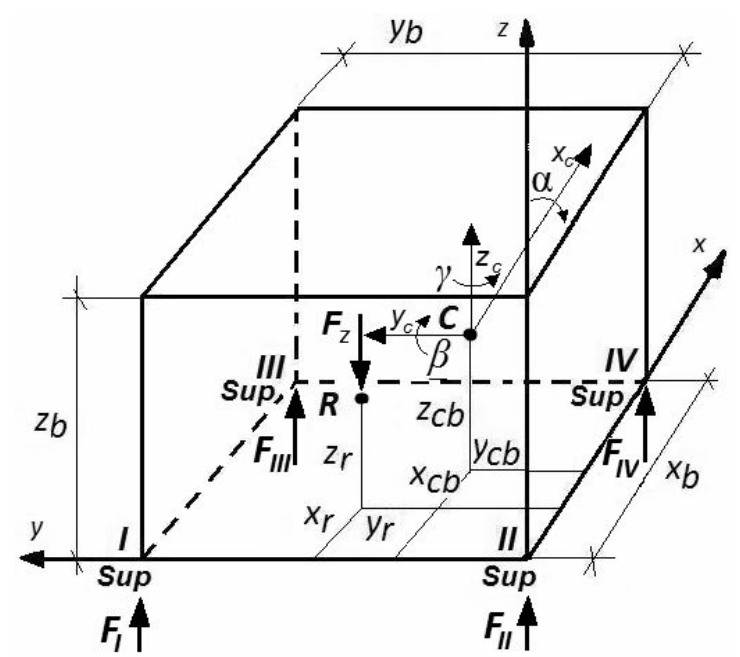

Fig. 1. The shape and the parameters of the investigated body

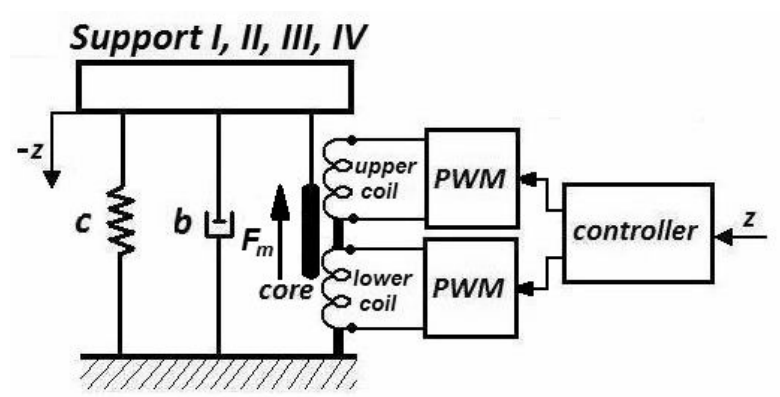

Fig. 2. The composition of the supports $z$ - support displacement, $F_{m}$ - magnetic force

There are a lot of machines and apparatuses for which the dynamics model can be presented in that way. Depending on the dimensions, a small computerized numerical control (CNC) machine tool, an air compressor, a refrigerator, and other devices can be described. Selected values of the body parameters are given in Table 1.

\subsection{Body analysis}

The rigid body of the 3-degrees-of-freedom was taken into account. The body could move along $z_{c}$-axis and rotate around the $C$ point $(\alpha, \beta$ - rotation co-ordinates, are depicted in Fig. 1). We assumed that other motions are limited by the supports. Translational and rotational motions were described by Newton and Euler equations - respectively [3]:

$$
\begin{aligned}
& m_{b} \frac{d^{2} z_{c}}{d t^{2}}=-F_{z}+F_{I}+F_{I I}+F_{I I I}+F_{I V}-m_{b} g \\
& I_{c x} \frac{d^{2} \alpha}{d t^{2}}=-F_{z}\left(y_{r}-y_{c b}-e_{r} \cos \left(n_{r} \frac{\pi}{30} t\right)\right)+\ldots \\
& +F_{I}\left(y_{b}-y_{c b}\right)-F_{I I} y_{c b}+\ldots \\
& +F_{I I I}\left(y_{b}-y_{c b}\right)-F_{I V} y_{c b} \\
& I_{c y} \frac{d^{2} \beta}{d t^{2}}=-F_{z}\left(x_{c b}-x_{r}\right)+F_{I} x_{c b}+F_{I I} x_{c b}+\ldots \\
& -F_{I I I}\left(x_{b}-x_{c b}\right)+F_{I V}\left(x_{b}-x_{c b}\right)
\end{aligned}
$$

where:

$z_{c}-$ body mass centre translation, [m];

$\alpha, \beta$ - body rotation angles, [rad];

$g$ - gravity constant, $\left[\mathrm{m} / \mathrm{s}^{2}\right]$

$F_{z}-$ perturbation force, $[\mathrm{N}]$;

$F_{I}, F_{I I}, F_{I I I}, F_{I V}-$ supports forces, [N].

We calculated that the maximum influence of part

$e_{r} \cdot \cos \left(n_{r} \cdot(\pi / 30) \cdot t\right)$

on the expression

$$
F_{z} \cdot\left(y_{r}-y_{c b}-e_{r} \cdot \cos \left(n_{r} \cdot(\pi / 30) \cdot t\right)\right)
$$

Table 1

Model parameters

\begin{tabular}{|l|c|c|c|}
\hline \multicolumn{1}{|c|}{ Description } & Denotation & Value & Unit \\
\hline Body mass & $m_{b}$ & 100 & $\mathrm{~kg}$ \\
\hline Body dimensions & $x_{b} \times y_{b} \times z_{b}$ & $1 \times 1 \times 1$ & $\mathrm{~m}$ \\
\hline Body mass centre coordinates & $x_{c b} \times y_{c b} \times z_{c b}$ & $0.45 \times 0.4 \times 0.5$ & $\mathrm{~m}$ \\
\hline$X_{c}$ axis mass moment of inertia & $I_{c x}$ & 15.7 & $\mathrm{~kg} \cdot \mathrm{m}^{2}$ \\
\hline$\underline{Y}_{c}$ axis mass moment of inertia & $I_{c y}$ & 16.4 & $\mathrm{~kg} \cdot \mathrm{m}^{2}$ \\
\hline Rotor location coordinates & $x_{r} \times y_{r} \times z_{r}$ & $0.2 \times 0.65 \times 0.5$ & $\mathrm{~m}$ \\
\hline Rotor mass & $m_{r}$ & 10 & $\mathrm{~kg}$ \\
\hline Speed of rotation & $n_{r}$ & $6 \div 1800$ & $\mathrm{rpm}$ \\
\hline Rotor eccentric & $e_{r}$ & 0.5 & $\mathrm{~mm}$ \\
\hline
\end{tabular}


is only $\pm 0.33 \%$, so we simplified the equation (2) to the following form:

$$
\begin{aligned}
& I_{c x} \frac{d^{2} \alpha}{d t^{2}}=-F_{z}\left(y_{r}-y_{c b}\right)+F_{I}\left(y_{b}-y_{c b}\right)-F_{I I} y_{c b}+\ldots \\
& +F_{I I I}\left(y_{b}-y_{c b}\right)-F_{I V} y_{c b}
\end{aligned}
$$

The perturbation in the system was introduced by the unbalanced rotor and affected only in the $z$-direction.

$$
F_{z}=m_{r} e_{r}\left(n_{r} \frac{\pi}{30}\right)^{2} \sin \left(n_{r} \frac{\pi}{30} t\right)
$$

The displacements in the supports were obtained from geometrical relations $\left(z_{I}, z_{I I}, z_{I I I}, z_{I V}\right)$. Forces generated in the supports were described in the following way:

$$
\begin{aligned}
& F_{I}=c z_{I}+b \frac{d z_{I}}{d t}+F_{m I} \\
& F_{I I}=c z_{I I}+b \frac{d z_{I I}}{d t}+F_{m I I} \\
& F_{I I I}=c z_{I I I}+b \frac{d z_{I I I}}{d t}+F_{m I I I} \\
& F_{I V}=c z_{I V}+b \frac{d z_{I V}}{d t}+F_{m I V}
\end{aligned}
$$

The spring's stiffness $(c)$ and damping coefficients $(b)$ were selected as follows: $c=10000 \mathrm{~N} / \mathrm{m}, b=75 \mathrm{~N} \cdot \mathrm{s} / \mathrm{m}$. $F_{m I}, F_{m I I}, F_{m I I I}$ and $F_{m I V}$ represent the forces of the electromagnetic actuators.

\subsection{The control system}

The coil with a movable ferromagnetic core was introduced in each body support as an actuator (Fig. 3). According to the references (COMSOL 2010, Iserman 2005, MATLAB 2010), in such devices, magnetic force can be calculated from the following equations:

$$
\left\{\begin{array}{c}
W_{m}=\frac{L_{s} i_{c}^{2}}{2} \\
F_{m}=-\nabla W_{m} \Rightarrow F_{m}\left(z_{s}\right)=-\frac{\partial W_{m}}{\partial z_{s}}
\end{array}\right.
$$

where:

$W_{m}-$ magnetic energy (work of magnetic field), [J];

$L_{s}-$ system inductance, $[\mathrm{H}]$;

$i_{\mathrm{c}}-$ coil current, [A];

$z_{s}-$ displacement in the particular support, [m].

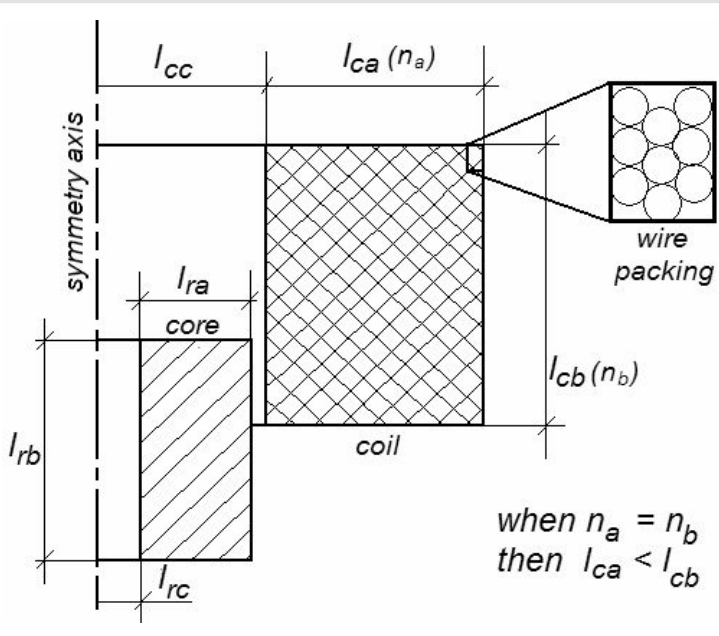

Fig. 3. The coil-core system

From equations (12) we can get:

$$
F_{m}\left(z_{s}, i_{c}\right)=-\frac{1}{2} \frac{\partial L_{s} i_{c}{ }^{2}}{\partial z_{s}}=-\frac{1}{2}\left(L_{s} \frac{\partial i_{c}{ }^{2}}{\partial z_{s}}+i_{c}{ }^{2} \frac{\partial L_{s}}{\partial z_{s}}\right)
$$

where $d L_{s} / d z_{c}$ - inductance gradient, $[\mathrm{H} / \mathrm{m}]$.

When we assumed that the coil current was independent of the core displacement $\left(d i_{c} / d z_{s}=0\right)$, we got the following magnetic force equation:

$$
F_{m}\left(z_{s}, i_{c}\right)=-\frac{1}{2} i_{c}{ }^{2} \frac{d L_{s}}{d z_{s}}
$$

We selected coils consisting of 138 turns of $1.2 \mathrm{~mm}$ wire diameter. The coils were composed of 12 turns of wire per length $\left(n_{b}\right)$ and 12 layers $\left(n_{a}\right)$ and their resistance was $0.2 \Omega$ The dimensions of the described system are presented in Figure 3 and in Table 2.

Table 2

Dimensions of the selected coil-core system

\begin{tabular}{|l|c|c|c|}
\hline \multicolumn{1}{|c|}{ Description } & Denotation & Value & Unit \\
\hline Coil thickness & $l_{c a}$ & 12.6 & $\mathrm{~mm}$ \\
\hline Coil length & $l_{c b}$ & 14.4 & $\mathrm{~mm}$ \\
\hline Coil inner radius & $l_{c c}$ & 10 & $\mathrm{~mm}$ \\
\hline Core thickness & $l_{r a}$ & 7 & $\mathrm{~mm}$ \\
\hline Core length & $l_{r b}$ & 14.4 & $\mathrm{~mm}$ \\
\hline Core inner radius & $l_{r c}$ & 2.5 & $\mathrm{~mm}$ \\
\hline
\end{tabular}

As the core, a sleeve-shaped soft iron material with relative permeability of 4000 was used. The system was modelled in COMSOL Multiphysics software by means of the finite element method (FEM) (COMSOL 2010). Thus, the inductance and inductance gradient of the system were calculated. In the computations we took advantage of the system symmetry (Fig. 4). 


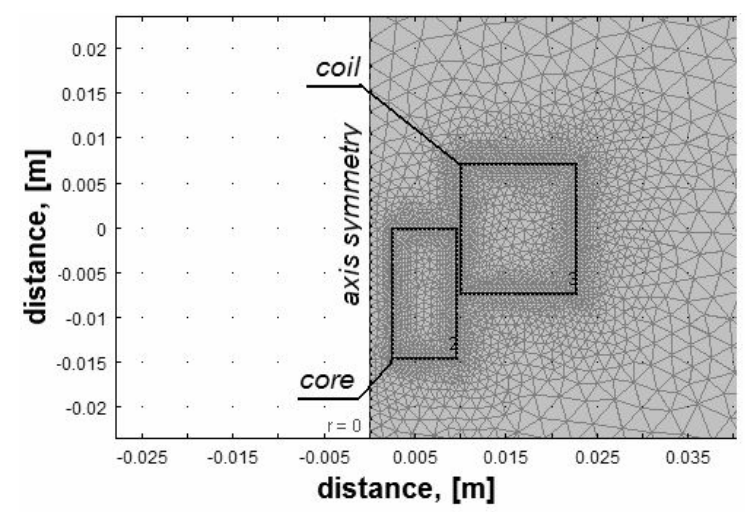

Fig. 4. FEM model mesh

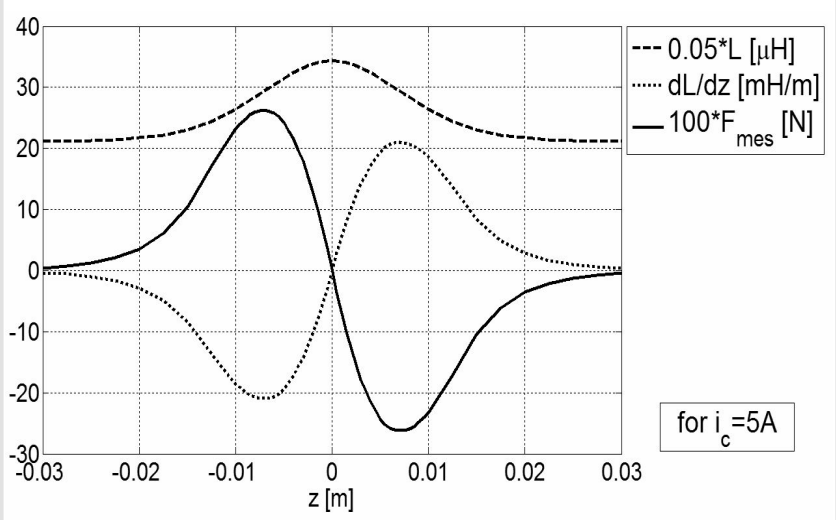

Fig. 5. Distribution of inductance, inductance gradient and magnetic force along coil $z$-axis

The relations between the core position, magnetic force, inductance and inductance gradient are shown in Figure 5. The investigated system can be treated as an active spring in which the spring coefficient depends on coil current value. The voltage equation of the single coil-core system can be written as:

$$
u_{c}=u_{R}+u_{L}
$$

where:

$u_{c}-$ voltage applied to the electromagnetic circuit, [V];

$u_{r}$ - voltage drop on coil resistance, [V];

$u_{L}$ - voltage drop on coil inductance, [V].

Equation (16) can be expressed as:

$$
u_{c}=R_{c} i_{c}+\frac{d \psi_{s}}{d t}
$$

where:

$\psi_{s}$ - magnetic linkage flux, [Wb];

$R_{c}-$ coil resistance, [ $\left.\Omega\right]$.

Under the consideration that $\psi_{s}=L_{s} \cdot i_{c}$ and the fact that inductance $\left(L_{s}\right)$ depends on the core position $\left(z_{c}\right)$, equation (16) can be written in the following form:

$$
u_{c}=R_{c} i_{c}+L_{s} \frac{d i_{c}}{d t}+i_{c} \frac{d L_{s}}{d z_{s}} \frac{d z_{s}}{d t}
$$

In this paper, the relation between system inductance and coil current was not taken into consideration. In order to conduct the simulations of the magnetic actuator, the following state equation was applied into the model:

$$
\frac{d i_{c}}{d t}=\left(-\frac{R_{c}+\frac{d L_{s}}{d z_{s}} \frac{d z_{s}}{d t}}{L_{s}}\right) i_{c}+\frac{1}{L_{s}} u_{c}
$$

When we took into account a small amplitude of the core vibrations, we did not get sufficient control force in spite of the high current value. In order to increase the magnetic force in the single support, we decided to use two coils instead of one. Distances between the coils equalled $0.6 \mathrm{~mm}$. Four cores were placed in the points of the supports static deflection. The cores were placed $7.5 \mathrm{~mm}$ from the both coil centres. In such positions the magnetic force reached almost maximal value. The diagram of the described system was presented in Figure 6. The proposed approach allowed us to control the stiffness of the electromagnetic actuator by means of an electric current. Moreover, it also enabled us to generate magnetic forces at zero position (the static deflection point). The relation between magnetic force and coil current is presented in Figure 7.

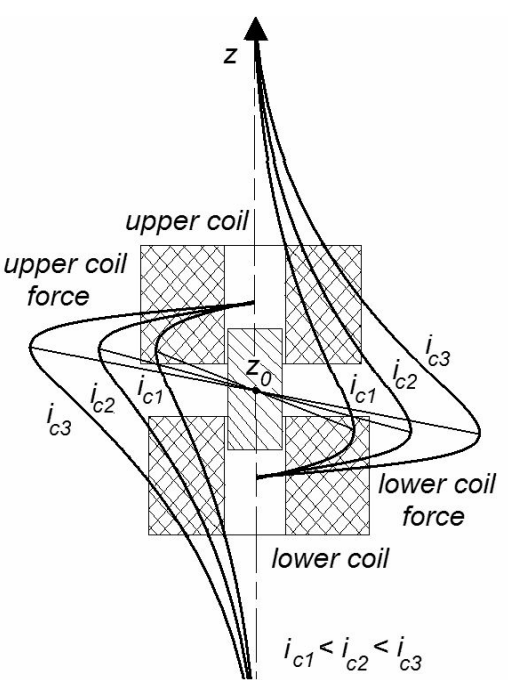

Fig. 6. Distribution of magnetic force along $z$-axis of the two-coils electromagnetic actuator

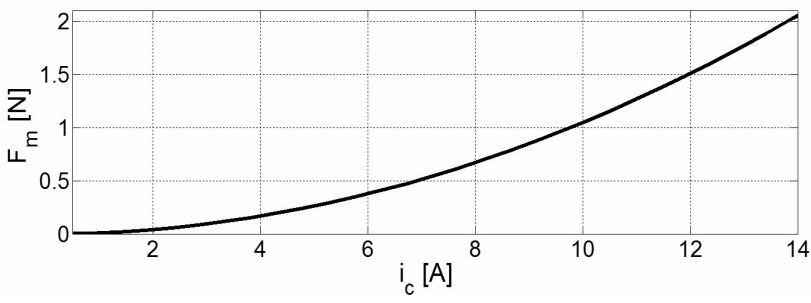

Fig. 7. Relation between coil current and magnetic force acting on the core located in the point of static deflection (between coils $-7.5 \mathrm{~mm}$ from their centres) 
The described electromagnetic actuators should react to the introduced perturbations so, the selected coils should have bandwidths which contain all the frequencies of the perturbation too. In our case, the disturbance was caused by a statically unbalanced rotor which could rotate with maximum speed of $1800 \mathrm{rpm}$ (it corresponds to $30 \mathrm{~Hz}$ ). We obtained the amplitude characteristics of the executive elements. In Figure 8, the relation between coil current and magnetic force is presented. The calculations were conducted in the working point where the maximal magnetic force acted on the core.

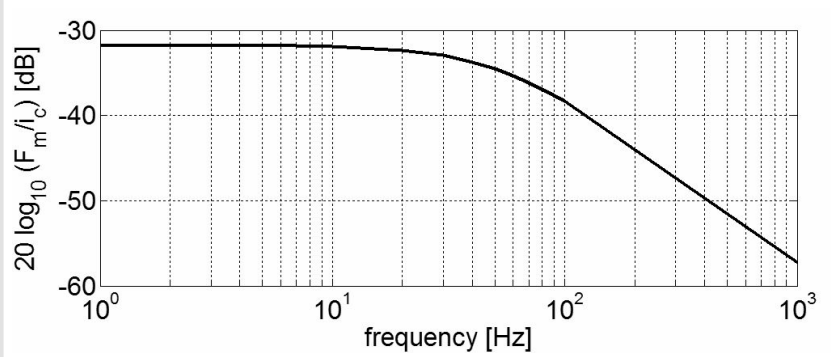

Fig. 8. Amplitude characteristic of selected coil-core system (core located $7.5 \mathrm{~mm}$ from coil centre)

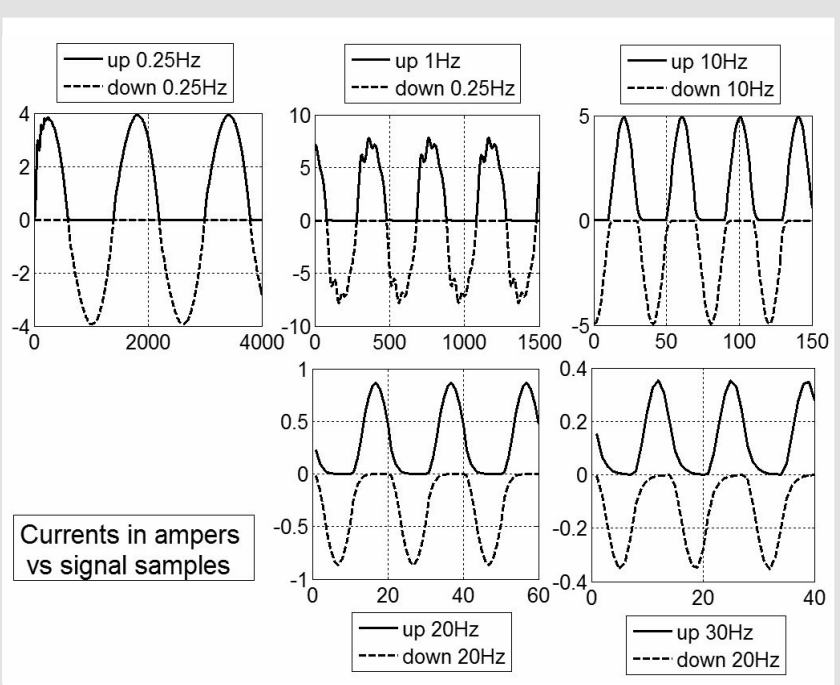

Fig. 9. Currents in the upper and the lower coil as result of displacement in support I caused by perturbation

In our research we assumed that at one moment only one coil worked. Therefore, the magnetic field of the upper coil had no influence on the current flow in the lower one and vice versa. We omitted the mutual inductance of the system. Currents flowing through the coils at selected perturbation frequencies $(0.25,1,10,20$ and $30 \mathrm{~Hz})$ are presented in Figure 9. The amplitude of the coil current decreases at higher frequencies because the bandwidth of the selected coil is exceeded. Moreover, in the calculations the following simplifications were assumed:

- system worked in the area without magnetic saturation;

- eddy currents flowing through the core were neglected;

- friction between core and coil was omitted;

- coils were fixed to a stationary base;

- each core was connected to the vibrating body by joint;

- control force acted only in the $z$-direction.
In the system, the coils currents were controlled by means of PD regulators and the pulsed-width modulated (PWM) generators. The selected control law has the following form:

$$
u_{P D}(t)=k_{p}\left(e(t)+\frac{T_{d}}{k_{d}} \frac{d}{d t} e(t)\right)
$$

where:

$$
\begin{aligned}
u_{P D}(t) & - \text { controller output (PWMs impulses width); } \\
k_{p} & - \text { controller proportional gain coefficient; } \\
T_{d}- & \text { derivation time; } \\
k_{d}- & \text { dynamic gain coefficient; } \\
e(t) & - \text { regulation error ( } z \text {-displacement in the parti- } \\
& \text { cular support). }
\end{aligned}
$$

PWMs frequency and voltage were $10 \mathrm{kHz}$ and $100 \mathrm{~V}-$ respectively. The designed controller should improve system damping in the range of perturbation frequencies. The settings of the regulators were selected manually by means of frequency characteristic simulation.

\section{SIMULATION RESULTS}

All of the parts of the described control system were simulated in MATLAB and Simulink software (MATLAB 2010, Mrozek and Mrozek 2010). At the beginning of the simulation, the investigated body supports were in the horizontal plane specified by no-loaded supports springs, and dampers (the displacement in the four supports equalled zero). The body reached a steady state under the influence of the gravity force. In spite of identical springs used in each support, the static deflections were different because the body mass centre was not coincided with the geometric centre. Transition to the steady state was shown in Figures 10 and 11 (non-controlled model without $F_{z}$ perturbation).

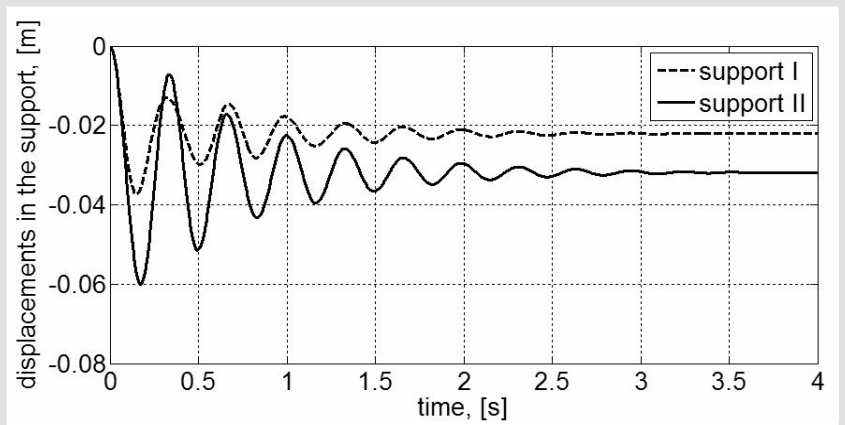

Fig. 10. Transition to the steady state in the support I and II

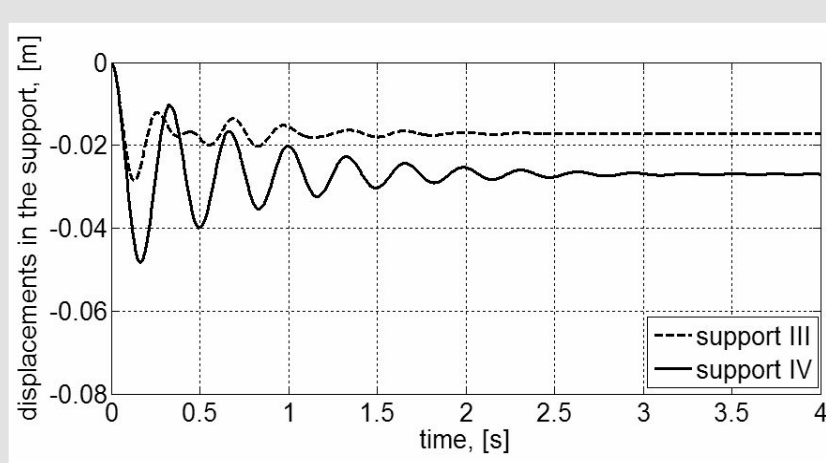

Fig. 11. Transition to the steady state in the support III and IV 


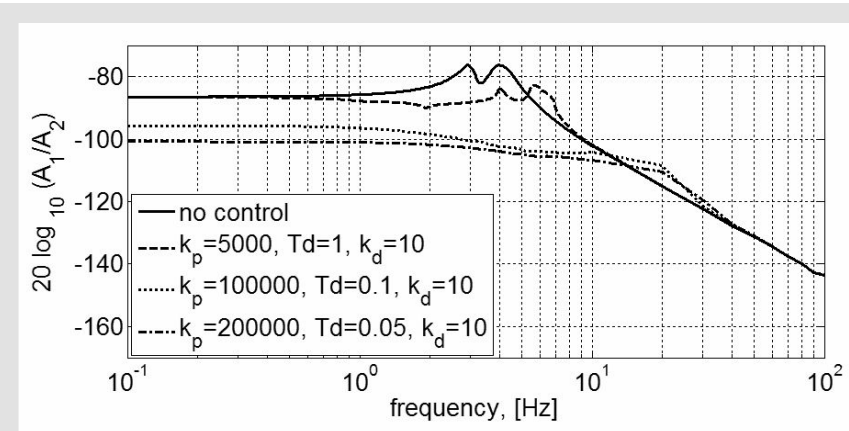

Fig. 12. System frequency responses to perturbation $F_{z}=\sin (2 \cdot \pi \cdot f \cdot t)$

$\mathrm{A}_{1}$ - displacement in the support I, $\mathrm{A}_{2}$ - perturbation amplitude

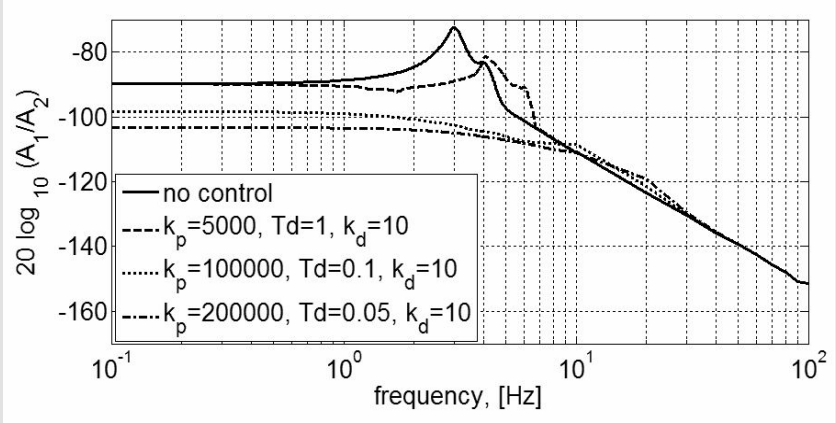

Fig. 13. System frequency responses to perturbation $F_{z}=\sin (2 \cdot \pi \cdot f \cdot t)$

$\mathrm{A}_{1}$ - displacement in the support II, $\mathrm{A}_{2}$ - perturbation amplitude

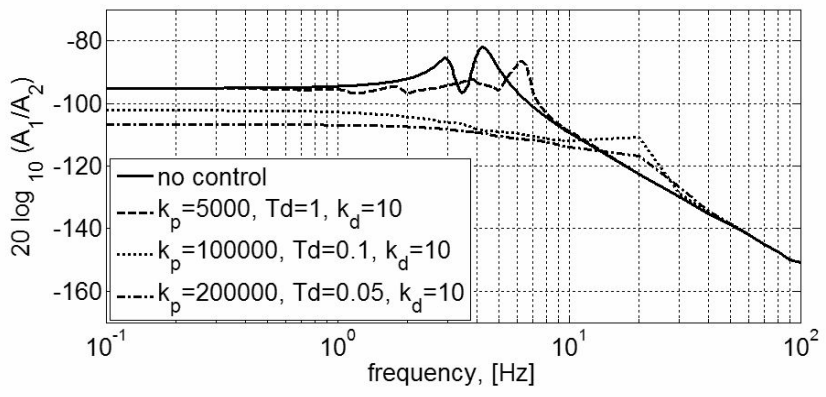

Fig. 14. System frequency responses to perturbation $F_{z}=\sin (2 \cdot \pi \cdot f \cdot t)$

$\mathrm{A}_{1}$ - displacement in the support III, $\mathrm{A}_{2}$ - perturbation amplitude

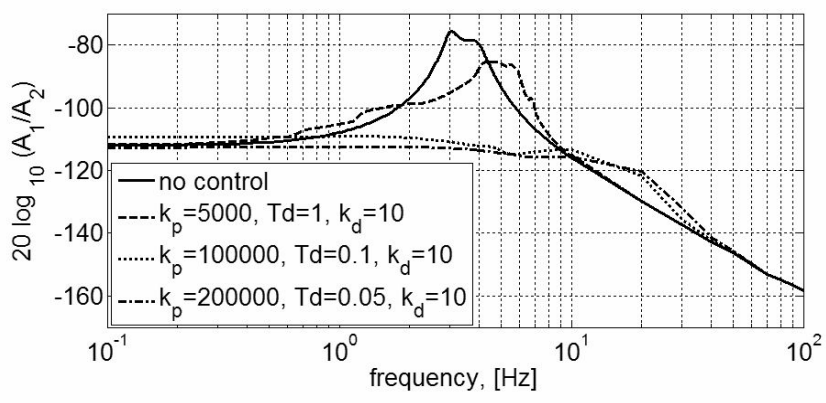

Fig. 15. System frequency responses to perturbation $F_{z}=\sin (2 \cdot \pi \cdot f \cdot t)$

$\mathrm{A}_{1}$ - displacement in the support IV, $\mathrm{A}_{2}$ - perturbation amplitude
In the next step, the system frequency responses ware calculated. The system was excited by the force of the equation $\mathrm{A}_{2} \cdot \sin (2 \cdot \pi \cdot f \cdot t)$ where $f$ was a frequency and $\mathrm{A}_{2}$ was an amplitude equalled $1 \mathrm{~N}$. Frequencies were changed from 0.1 to $100 \mathrm{~Hz}$. We made a comparison between the noncontrolled system and the system controlled by means of PD regulators. The selected frequency characteristics were presented in Figures 12-15.

The described calculations allowed us to select the PD controller settings which could improve damping in the system and modify its frequency responses. In order to respond quickly and strongly, the controller should have high proportional gain. In the proposed control system, the $k_{p}$ value resulted from a small displacement in the particular support. The single support control system consisted of a PD regulator, two PWMs, and a coils-core actuator. As the input of the complete control system the support displacement was used. The resultant magnetic force was output thus, the controller gain setting could be treated as a measure of the additional stiffness introduced by the proposed active control system.

In the next part of the research we considered how the control system managed to compensate the influence of the perturbation introduced by the statically unbalanced rotor. According to the equation (5), when the rotational speed increased, the amplitude of the disturbing force increased also, but in exponential way. It was taken into account in our calculations. The rotational speed was changed from 6 to $1800 \mathrm{rpm}$. In Figures 16-19, the comparison of the system responses is presented.

\section{CONCLUSIONS}

In this paper we presented an introductory investigation concerning an active coil-core system which could influence the vibrations of a selected rigid body. The solenoid actuators were added to the vibroisolated body supports which resulted in the modification of the system frequency responses. The results of the calculations showed that the active coils with a movable core can improve vibration damping and suppress the resonances of the system. However, due to the narrow bandwidth of the selected actuators, the vibroisolated system could be actively controlled only up to $10 \mathrm{~Hz}$ frequency range (shown in Figures 12-15).

According to the reference (Gosiewski 2003), we took into consideration the current density not higher than 6-9 $\mathrm{A} / \mathrm{mm}^{2}$. Thus, the current in the coils attained a maximum value of $10 \mathrm{~A}$. During the simulations, the width of the PWMs impulses temporarily reached saturation so, at that time, the control system could not efficiently suppress the body vibrations.

The proposed control system reacted on the $z$-displacement in the particular supports. Therefore, its responses to statically unbalanced rotor perturbations were limited to the narrow range of the rotational speeds (up to $300 \mathrm{rpm}$ ). 


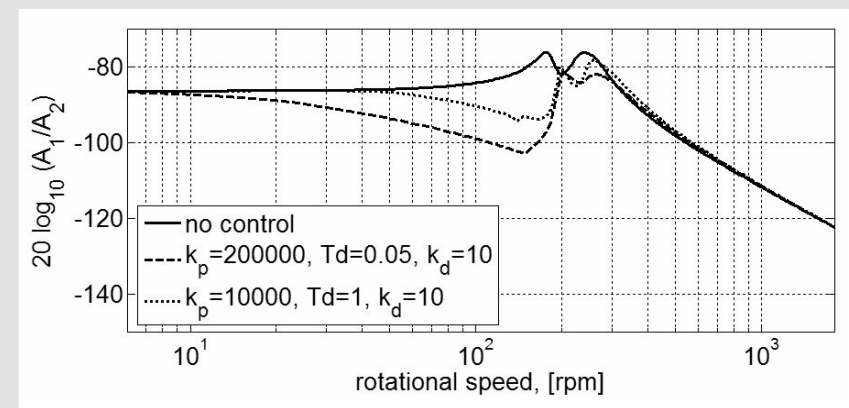

Fig. 16. System responses to unbalanced rotor perturbations $\mathrm{A}_{1}$ - displacement in the support I,

$\mathrm{A}_{2}$ - perturbation amplitude

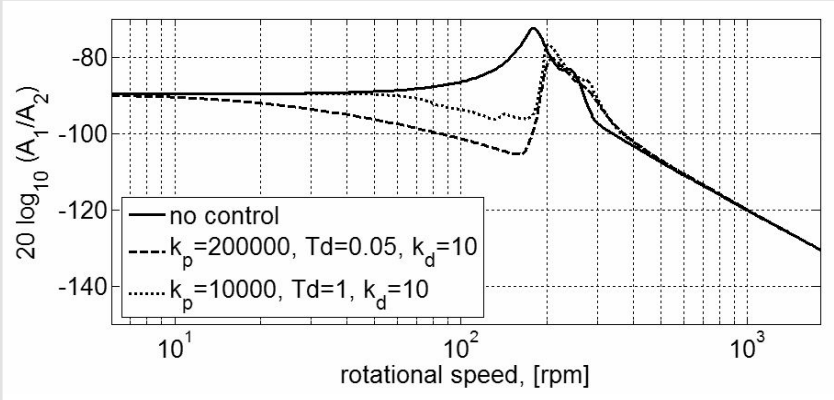

Fig. 17. System responses to unbalanced rotor perturbations $A_{1}$ - displacement in the support II, $\mathrm{A}_{2}$ - perturbation amplitude

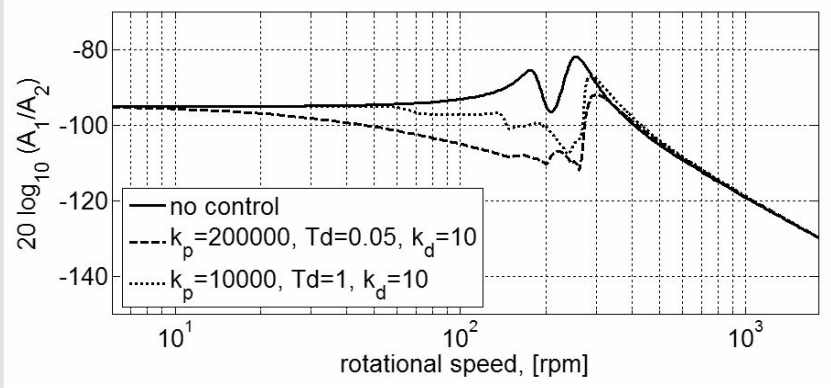

Fig. 18. System responses to unbalanced rotor perturbations $\mathrm{A}_{1}$ - displacement in the support III, $\mathrm{A}_{2}$ - perturbation amplitude

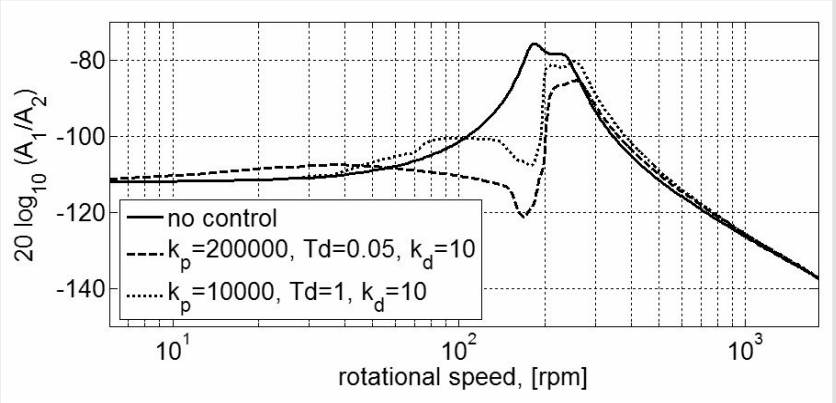

Fig. 19. System responses to unbalanced rotor perturbations $\mathrm{A}_{1}$ - displacement in the support IV, $\mathrm{A}_{2}$ - perturbation amplitude

However, the calculated characteristics showed that it was sufficient for the investigated body case. The amplitudes of the vibrations in each support decreased in the range of system resonances by the introduced electromagnetic actuators (Figs 16-19).

The described results of conducted simulations proved that, in the low range of frequencies the investigated electromagnetic systems can be used as active vibration dampers. Their influence was noticed in spite of the small dimensions of the actuators (Tab. 2) and the relatively small values of magnetic force (about $1 \mathrm{~N}$ for 10 A current shown in Fig. 7). The main disadvantages of the proposed active system are connected to electro-mechanical system modelling problems such as nonlinearities, eddy currents, magnetic saturations, mechanical friction or thermal effects of current flow. In order to put the proposed solution into practice, some improvement should be done. One -and the most important- of them is to increase the coil-core system bandwidth by for example, using better PWM generators of higher voltage amplitude and frequency. Future research could also be devoted to the improvement of classic PID regulators settings. The design of more sophisticated control laws using for example, feedback linearization or vibration velocity signals should also be considered.

Summarising, coil-core actuators are very interesting mechatronic objects and in spite of their disadvantages should be further investigated and tested.

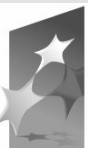

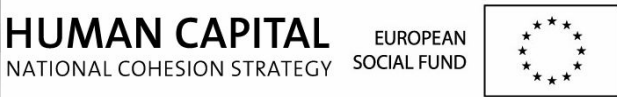

\section{Acknowledgement}

M. Kondratiuk's work was supported by the European Union within the European Social Found (agreement no. WIEM/POKL/DOK/2010/1).

\section{References}

COMSOL Multiphysics v4.1 2010, User's Guide, COMSOL AB.

Goliński J.A. 1979, Wibroizolacja maszyn i urzadzeń (in Polish), Wydawnictwo Naukowo-Techniczne, Warszawa, ISBN 83-204-0067-8.

Gosiewski Z., Falkowski K. 2003, Wielofunkcyjne tożyska magnetyczne (in Polish), Wydawnictwa Naukowe Instytutu Lotnictwa, Warszawa, ISBN 83-915995-5-8.

Iserman R. 2005, Mechatronic Systems Fundamentals, Springer-Verlag, London Limited.

Korzeniowski R. 2004, Zastosowanie zespolu pneumohydraulicznego w aktywnych układach redukcji drgań mechanicznych (in Polish), AGH Wydział Inżynierii Mechanicznej i Robotyki, Kraków, (PhD Thesis Dissertation).

Kowal J. 1996, Sterowanie drganiami (in Polish), Gutenberg, Kraków, ISBN 83-86310-06-5.

Martynowicz P. 2006, Synteza algorytmów sterowania drganiami dla płaskiego modelu magnetoreologicznego zawieszenia pojazdu (in Polish), AGH Wydział Inżynierii Mechanicznej i Robotyki, Kraków, ( $\mathrm{PhD}$ Thesis Dissertation).

MATLAB and Simulink 2010, User's Guide, MathWorks.

Mrozek B., Mrozek Z. 2010, MATLAB i Simulink (in Polish), Helion, Gliwice, ISBN 978-83-246-2564-2.

Osiński Z. 1979, Ttumienie drgań mechanicznych (in Polish), Państwowe Wydawnictwo Naukowe, Warszawa, ISBN 83-01-00553-X

Sapiński B. 2004, Linear Magnetorheological Fluid Dampers for Vibration Mitigation: Modelling, Control and Experimental Testing, AGH Uczelniane Wydawnictwo Naukowo-Dydaktyczne, Kraków, ISSN 0867-6631. 